\title{
The Impact of Task-Based Instruction on Reading Comprehension Ability among the Iranian EFL students
}

\author{
Hamideh Rezaie \\ Department of Language and Literature, Larestan Branch \\ Islamic Azad University, Larestan, Iran \\ E-mail: hamideh_rezaie1080@yahoo.com \\ Abusaied Janfaza \\ Department of Foreign Languages, Bandar Abbas Branch \\ Islamic Azad University, Bandar Abbas Iran \\ E-mail: s_janfaza@hotmail.com \\ Afshin Soori \\ Department of Language and Literature, Larestan Branch \\ Islamic Azad University, Larestan, Iran \\ E-mail: afshin_soori@yahoo.com
}

Received: 24-01-2014

doi:10.7575/aiac.ijalel.v.3n.4p.97
Accepted: 16-03-2014

Published: 01-07-2014

URL: http://dx.doi.org/10.7575/aiac.ijalel.v.3n.4p.97

\begin{abstract}
The current study investigated the effect of task-based instruction in improving the reading comprehension ability among the Iranian EFL students. To conduct this study, a sample of 80 Iranian EFL students in Islamic Azad University, Larestan, Iran served as the participants of the study. After the administration of an Oxford Placement Test as the pre-test, the students were randomly assigned into experimental and control groups. During the treatment, the students in the experimental group received some reading comprehension tasks, and the students in the control group received a placebo. At the end of the treatment, the students in both groups were administered a post-test. The result of this study revealed that the students in experimental group outperformed the students in the control group. In other words, task-based instruction was effective in increasing the reading comprehension ability.
\end{abstract}

Keywords: Tasks, Language learning development, Reading comprehension, EFL students

\section{Introduction}

It is mostly believed that an important language ability and a central means for learning new information in a second or foreign language context is reading comprehension. It is one of the most important skills which are essential for the students' success and it may enhance the process of language acquisition as well as it assisting the learners to learn different materials for many different purposes. The ability to read means extracting the information from the textand connect with the information they already have. Reading is a kind of meaning-construction process and it involves "an interaction between text and reader, careful attention, memory, perceptual and comprehension processes, understanding words and sentences, along with a complex integration of the prior knowledge, language proficiency, and metacognitive strategies" (Poorahmadi, 2012, p.29). Readers can improve their reading comprehension of textbooks assignments and direction on exams via appropriate reading materials. To Hadley (2003), proper materials can be supportive when the students try to comprehend the discourse structure and the organization of the reading passage. If the students are familiar with different types of reading materials, then reading comprehension can be improved. Moreover, reading comprehension will be increased if "such materials are related to understanding the plain facts as well as the implications, suppositions, and evaluations of the text" (Grabe\&Stoller, 2001, as cited in Poorahmadi, 2012, p.30).

During the past decades the view of teaching reading comprehension has been changed drastically. Task-based approach is different from the traditional teaching methods. In fact, in task-based approach lessons are in terms of required language to perform a set of tasks rather than based on some aspects of language such as structure and vocabulary.

It seems that task-based approach are being used widely for the learning of a second or foreign language. Willis and Willis (2007) divided task-based approach into three sections: the pre-task, the task-cycle, and the language focus.

Prabhu was the first one developed task-based learning. According to Prabhu (1987), students are able to learn more effectively when their minds are concentrated on the task. Other researchers like Fang-jinang's (2005) explored how task-based approach was effective among the primary school students. The result of this study revealed that the performance ofexperimental group (TBA) wasimproved after the instruction. 
A large of number researchers (e.g.Chodkieiwicz,2001; Ellis, 2000; Hadley, 2003; Rivers, 1990; Skehan, 1998; Wallace, 2001) have expressed the role of authentic materials in the form of tasks in improving the reading comprehension ability. To Carter and Nunan (2001), task is considered as "an activity in the classroom which involves language use to achieve a communicative purpose" (p. 227). For Ellis (2003) "tasks are activities that call for primarily meaning focused language use" (p.3).

Pica (1997) refers to this fact that a pedagogical task has an important role in second language acquisition and also for language teachers. Corder (1981) believes that task is considered as a means of eliciting samples from language learners and as Prabhu (1987) states it can be a device that organizes the content and methodology of language teaching.

In language classrooms, tasks can be used for practicing a particular structure, function, or sub-skill. According to Ellis (2003),tasks provide a purpose for activity which is beyond the practice of language for its own sake. Fulfilling a task needs the active participation and cooperation of the students, and the students should exchange information on a problem they have faced through the task.

Reading tasks are to some extent different from reading exercises.Nunan (1999) refers to the distinction among task, exercise and activity. To Nunan (1999), task is a communicative act which usually does not include a restrictive focus on a single grammatical structure. An exercise usually concentrates on a single language element and it contains a linguistic outcome. An activity includes a restrictive concentration on one or more language items. However, learners are required to participate in an activity as language users through the tasks and they should focus on meaning conveyance (Poorahmadi, 2012). Therefore, the same communicative processes involving in the real world activities should be employed by learners. Exercises may contain some purely language related results. In contrast, tasks may include non-linguistic results and language results. To Poorahmadi (2012), helpful comprehension tasks will be challenging, they keep the students' interest, maintain the students' efforts at task completion, and help them to concentrate on meaning.

The review of related literature indicates the improving of reading comprehension ability can be considered as a demanding procedure and it will help the acquisition of a second language. Like any other EFL contexts, the importance of reading comprehension is undeniable in Iran. Therefore, this issue has attracted the attention of many researchers and applied linguists. However, it seems that the majority of Iranian students may confront some problems to improve their reading abilities. Although, some solutions have been proposed dealing with this weakness among the students, they did not seem to be applicable. Consequently, the students require a reasonable solution for their reading deficiencies that has been remained vague so far. Moreover, this area needs more research which inspire the initiation of the current study. In this case, the main purpose of this study is to employ a task-based method of teaching reading comprehension and also investigates its impact on the improvement of reading ability in comparison to traditional and conventional methods of teaching reading comprehension. To come to these ends, the following research question is proposed.

1. What is the impact of task-based instruction on the reading comprehension ability among the Iranian EFL learners?

\section{Methodology}

\subsection{Participants}

The participants of the current study were a sample of 80 Iranian university students whose major was English in Islamic Azad University, Larestan, Iran. The sampling method for selection of the participants was a random selection. Thus, two groups of 40students in each group that were randomly selected to be in the experimental and control groups.

\subsection{Instruments}

The instruments of this study included Oxford Placement Test (OPT) and a final test which were administered to collect the required data. The OPT test was given to both groups as a pre-test to catch the initial differences among the students and as a post-test to explore the effects of treatment and how the students have improved. The final test was an end-of-the course test in terms of the students' course book which was Select Readings by (Lee \& Gunderson, 2001).

\section{Design and Procedure}

Both experimental and control groups received instruction for 15 sessions which was based on the ongoing university program. In this study, the regular university course and supplementary tasks were parts of the procedure. In each session, both groups covered a complete unit of their course book. Then, the students in the experimental group were received additional material. However, the students in the control group just received placebo in which they were asked to do some exercises in the textbook. This additional material contained some reading comprehension tasks. The researcher asked the students to work collaboratively on a number of tasks and report the results of those working tasks to their classmates. The tasks were taken from a number of sources (Doff \& Jones, 1999; Hartley \&Viney, 1984; Richards, 2002; Lee \&Gundersen, 2002). These tasks were organized from less challenging to most challenging "to keep their arrangement within the acceptable sequence of difficulty" (Poorahmadi 2012, p.31). Starting with less challenging tasks at the primary sessions familiarized the students with the characteristics of the tasks, and made them ready for doing challenging tasks. 
The students in experimental and control groups received a pre-test, a post-test, and a final test. The pre-test was Oxford Placement Test (OPT) which was given to whole students before placing the students in experimental and control groups. Then the students' scores on OPT were analyzed to ensure the homogeneity among the participants of this study before receiving the treatment. The OPT was re-administered at the end of the treatment to both-groups to compare the reading comprehension ability of both experimental and control groups. The final test that was a kind of achievement test made by the researcher as a teacher was conducted in terms of the students' course book. The aim of the final test was to measure the two groups' end ofthe course language proficiency development.

\section{Results}

In order to compute the reliability of the instruments, the researcher employed the Kuder-Richardson's reliability coefficient (KR-21). The results of Kuder-Richardson's reliability coefficient revealed that all pre, post, and the final tests were $.86, .88$, and .82 respectively, which were all within the range of acceptable reliability.

In order to be sure whether the students in both experimental and control groups are homogeneous at the beginning of the study in terms of their reading ability, a t-test was run on their test scores on the pre-test (OPT). As indicated in Table 1, the mean differences of the experimental and control group was 1.36 .

The results of the Levene's test revealed that two groups were homogeneous in terms of their variances. In other words, the same performance of the students in these two groups showed that they were equal in terms of reading comprehension ability at the beginning of the study before receiving the treatment.

Table 1. Independent T-test for pre-test

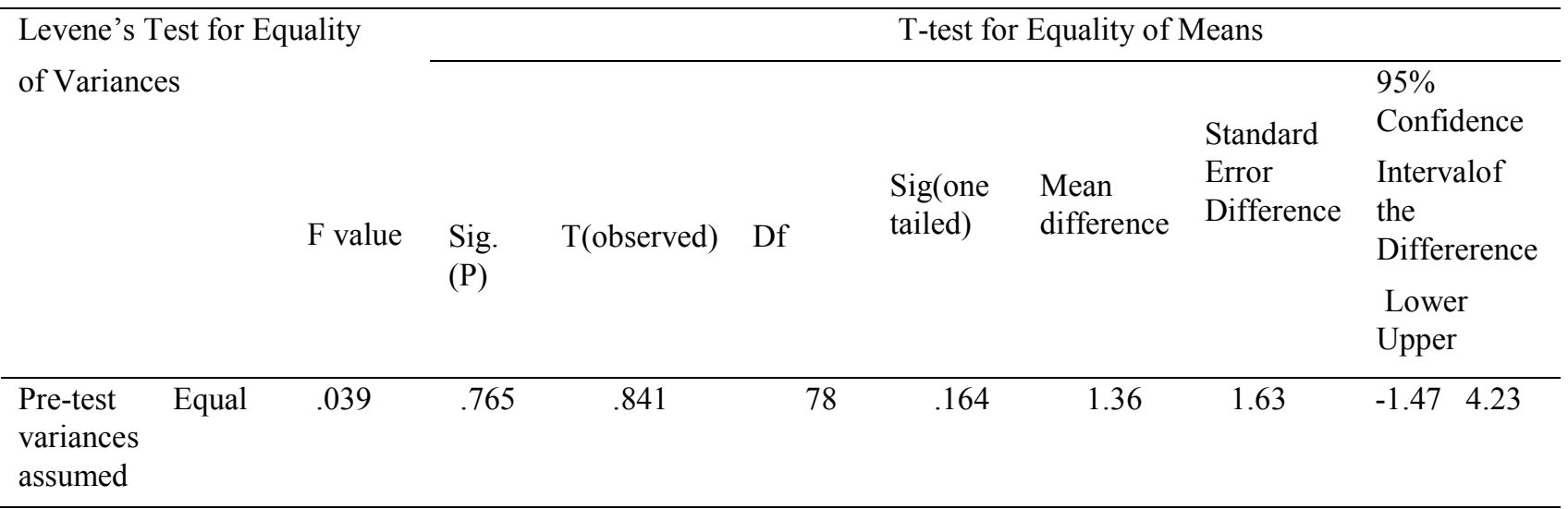

To explore whether the performance of experimental and control groups was improved in reading comprehension at the end of the treatment, a t-test was run to compare the mean scores of these two groups in the post-test.

As shown in Table 2, the T-observed value was $(\mathrm{t}=13.456)$. The $\mathrm{t}$-value at 78 degree of freedom is $(\mathrm{p}=.000$ onetailed) was higher than the critical T-value of 1.25 . The outcome indicated that there was a statistically significant difference between the mean scores of the experimental and control groups at the end of the study. It means that the students in the experimental group performed better than the students in the control group in the post-test.

Table 2. Independent T-test for post-test

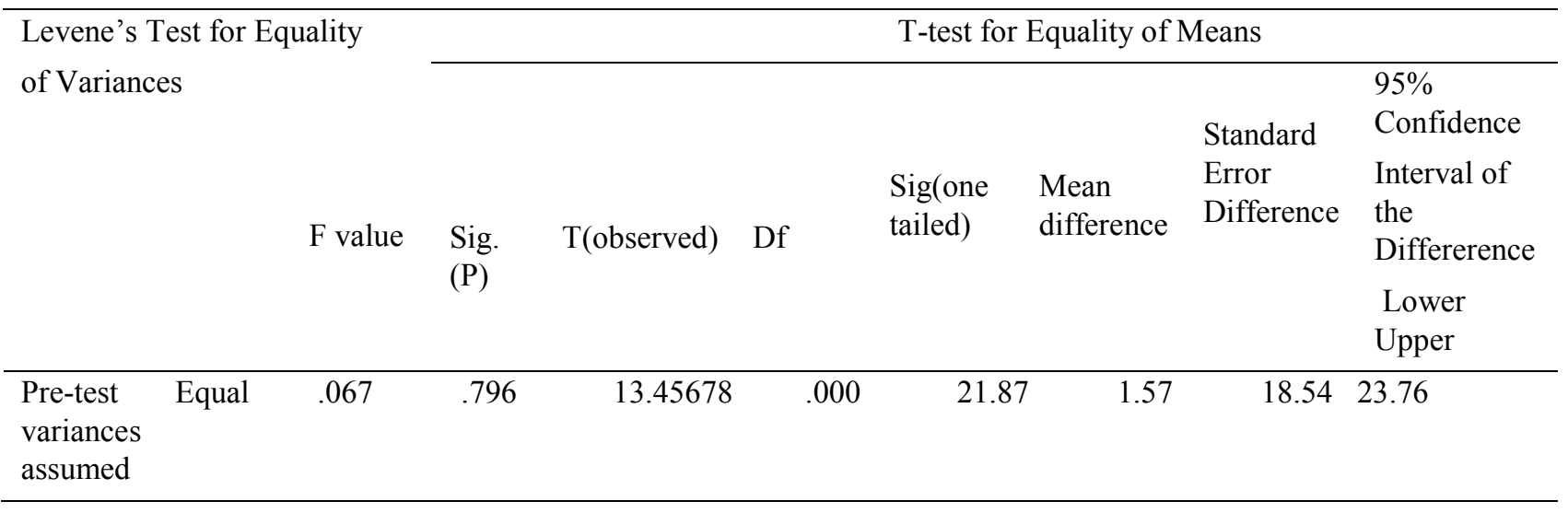

\section{Conclusion and discussion}

The current study investigated the effectiveness of implementing task-based approach in improving reading comprehension ability among the Iranian EFL students. This study also showed that classroom tasks are very effective in increasing the students' learning, because they "preserve situational and interactional authenticity to a large extent, 
can engage learners in using language pragmatically rather than displaying language, and require learners to employ cognitive processes such as selecting, classifying, ordering, reasoning, or evaluating information in order to carry out the task" (Poorahmadi 2012, p.33).

To answer research question, and investigate the effectiveness of task-based instruction on improving of the reading comprehension ability among the Iranian students, experimental research design was selected. To this end, the overall performance of the students in both experimental and control groups were examined. Their performance was also compared. The results of t-test which compared the performance of the students in both experimental and control groups in the post-test indicated a significant difference between the mean scores of these two groups. The students in the experimental group outperformed the students in the control group. These findings reveal that the task-based instruction can significantly improve the reading comprehension ability among the Iranian students.

The outcomes of this study were in line with the findings of other studies which considered tasks as valuable activities to be employed in the language classrooms. Regarding this issue, Skehan and Foster (1999) tasks have some influential effects on the nature of performance. Moreover, they are tasks which lead to "greater fluency and complexity, less dependably, and greater accuracy" (Poorahmadi 2012, p.34). Likewise, Willis and Willis (1987) examined the effectiveness of consciousness raising tasks to improve language learning. Other researchers like Lapkin and Swain (2000) referred to using jigsaw to examine the effectiveness of tasks as a scaffolding strategy for improving language learning.

The findings of the current study were adequately convincing to be employed successfully in EFL contexts like Iran. It can also give some insights to teachers and course designers to employ tasks in teaching syllabi. To this end, it is recommended that teachers incorporate tasks in their classrooms to improve reading skills among the Iranian students.

\section{References}

Chodkieiwicz, H. (2001). The acquisition of word meaning while reading in English as aforeign language. EUROSLA Yearbook, 1, 29-49.

Corder, S. P. (1981).Error analysis and interlanguage. Oxford: Oxford University Press.

Doff, A., \& Jones, C. (1999). Language in use: beginner. Classroom book. Cambridge: Cambridge University Press.

Ellis, R. (2000). Task-based research and language pedagogy.Language teaching research,4 (3), 193-220.

Fan-jian IC (2005).The effectiveness of implementing task-based instruction in a primary school in Taiwan.Unpublished master thesis, Yuan Ze University, Taiwan, R.O.C.

Grabe, W., \&Stoller, F. L. (2001). Reading for academic purpose: guidelines for ESL/EFLteacher. In M., CelceMurcia, Teaching English as a second or foreign language (3rd ed.,pp. 187-203). Boston, MA: Heinle\&Heinle.

Hadley, A. O. (2003). Teaching language in context (3rd ed.). Boston: Heinle\&Heinle Publishers.

Hartley, B., \&Viney, P. (1984). American streamline: Connections. Oxford: Oxford University Press.

Lapkin, S., \& Swain, M. (2000). Task-based second language learning: The uses of the first language. Language Teaching Research, 4 (3), 251-274.

Lee, L., \&Gundersen, E. (2001) Select reading: pre-intermediate. Oxford: Oxford University Press.

Nunan, D. (2001). Second language acquisition. In J., C. Richards \& W., A. Renandya, Methodology in language teaching: An anthology of current practice (pp. 87-99). Cambridge:Cambridge University Press.

Pica, T. (1997). Second language teaching and research relationships: a North Americanview. Language Teaching Research 1, 48- 72.

Poorahmadi, M. (2012).Investigating the efficiency of Task-Based instruction in improving reading comprehension ability, Journal of language and Translation, 3 (1), 29-36.

Prabhu, N. S. (1987). Second language pedagogy. Oxford: Oxford University Press.

Richards, J. C. (2002a). New interchange: English for international communication: book two. Cambridge: Cambridge University Press

Rivers, M. W. (1990). Speaking in many languages: Essays in foreign-language teaching (3rd ed.). New York: Cambridge University Press.

Skehan, P. (1998). Task-based instruction.Annual review of applied linguistics, 18, 268- 286.

Wallace, C. (2001). Reading. In R. Carter, \& D. Nunan (Eds.), The Cambridge guide toteaching English to speakers of other languages (pp. 7-13). Cambridge: Cambridge.

Willis, D. \& Willis, J. (1987).COBUILD Book 1. London: HarperCollins.

Willis D and Willis J (2007).Doing task-based teaching. Oxford, Oxford University Press. 